International Journal of English Literature and Social Sciences
Vol-6, Issue-1; Jan-Feb, 2021

\title{
The Role of School Heads' Supervision in Improving Quality of Teaching and Learning: A case of Public Secondary school in Ilemela District Mwanza Tanzania
}

\author{
Diana M. Ngole, Demetria Gerold Mkulu
}

Department of Educational Foundation, St. Augustine University of Tanzania, Mwanza, Tanzania

Received: 03 Nov 2020; Received in revised form: 30 Dec 2020; Accepted: 09 Jan 2021; Available online: 14 Jan 2021 (C2021 The Author(s). Published by Infogain Publication. This is an open access article under the CC BY license (https://creativecommons.org/licenses/by/4.0/).

\begin{abstract}
The main purpose of this study was to examine the role of heads of schools' supervision in improving quality of teaching and learning in public secondary schools in Ilemela District, Tanzania. The study was guided by three specific objectives which are to examine strategies used by head of schools in improving quality of teaching and learning, the challenges facing school heads in improving quality of teaching and learning, and possible initiatives used in addressing the challenges hindering effective school heads supervision that aim to improve the quality of teaching and learning in Ilemela District. The study was guided by total quality management theory (TQM). The research employed a mixed approach under convergent parallel research design. The study used a population of 86 comprising of 1 DEO, 4 WEO, 4 Head of Schools, 30 Teachers, and 47 Students. The researcher used questionnaires, interview and focus group discussion for data collection. Data was obtained and analyzed using Statistical Package for Social Sciences (SPSS) version 20 computer package. The data used descriptive statistics and the findings were presented by use of frequency tables, pie-charts. Also, part of qualitative data coded, categorized and used thematic analysis of which description were employed to present data in chapter four. The study found out that heads of schools are key instructional supervisors in schools. Furthermore, effective supervision was found to be the key factor for the academic performance in schools. The study recommended that heads of schools should be setting time for instructional supervision in schools because it is one of the roles that influence students' academic achievement positively. Also, the study recommends that the Ministry of Education, Science, and Technology (MOEST) should reinforce supervision-based training through seminars, workshops, and refresher courses countrywide for secondary school heads of schools and second masters/mistresses. By so doing, even those who missed out supervision course at the university or college could benefit.
\end{abstract}

Keywords - School head, Supervision, Public secondary schools, Quality teaching and learning.

\section{INTRODUCTION AND BACKGROUND TO THE STUDY}

The development of any society depends on quality of education, and the quality of education depends on the quality of teachers, students and effective involvement of parents in education (Paschal and Mkulu, 2020). To promote quality and effective education, cooperation in schools is important (Paschal, Nyoni, and Mkulu, 2020). In connection to that, the role of school head is essential to ensure supervision in the teaching and learning process.

Primarily, supervision in schools is acknowledged as a general leadership function intended to improve the performance of teachers' teaching and instruction (Cudjoe and Sarfo, 2016). The word supervision comes from two Latin words super and video where by super means over or above, while video means to see. Therefore, supervision simply means the function of leader to make difference in 
school organization through controlling and oversee teaching and learning process. Glickman and Gordon (2004) and Marecho (2012) insisted that, supervision in school organization is more potential towards determining the effectiveness of teaching and learning in school. Also, In Mohanty's(2008) views, teaching and learning supervision conveys the same general concept and is applied to both academic and administrative responsibilities.

According to Fisher (2011), the schools supervision includes all efforts of school officials directed to provide leadership to the teachers and other educational workers in the improvement of instruction. The improvement of teaching and learning in schools is the general purpose of supervision. A basic premise of supervision is that a teacher's instructional behavior affects student learning. An examination of instructional behaviors can lead to improvement in teaching and learning. The effective school research identifies schooling practice and characteristics associated with measurable improvements in student achievement and excellence among student achievement. These "effective school practices" include elements of schooling associated with a clearly defined curriculum; focused classroom instruction and management, firm consistent discipline, close monitoring of student performance; and strong instructional leadership

Supervision in a school system implies the process of ensuring that policies, principles, rules, regulations and methods prescribed for purposes of implementing and achieving the objectives for education are effectively carried out. Igwe (2001), Viewed that supervision involves the use of expert knowledge and experience to oversee, evaluate and coordinate the process of improving teaching and learning in schools. Supervision, through supporting teachers, controlling schools. Functioning and allowing for regular exchanges between schools, can be a powerful tool for quality improvement. This is rarely the case in Africa, probably even less so than elsewhere. Research on school supervision in Africa (De Grauwe 2001) shows the lack of satisfaction among teachers and supervisors with the impact of supervision on the classroom. The most evident reason and the one that supervisors regularly quote concerns the lack of resources. Many supervisors do not have the necessary vehicles nor the funds to travel, while at the same time the number of schools per officer has grown. Research at the end of the 1990s in four Southern African systems (Botswana, Namibia, Tanzania mainland and Zimbabwe) showed that a supervisor was on average responsible for over 150 teachers under him (De Grauwe 2001)
Archibong and (2012) highlighting the functional similarities states that supervision is administrative functions directed towards the efficient achievement of organizational goals. Their central purpose is to enhance productivity and both constitute tools for educational coordination. But the authors still find differences, thus: the words "supervision" and "inspection" are often used to mean the same but they are two different concepts in terms of job content and scope. Supervision is designed to achieve improvement in instruction, resolution of school constraints, maintenance of super ordinate-subordinate cooperation, professionalism and autonomy of staff and achievement of intrinsic motivation while Inspection is carried out specifically to ensure that minimum standards are maintained in the basic activities of teaching and learning. This is with regards to content coverage, resource provision, maintenance of discipline and keeping of statutory records and accounts. It also provides opportunities to access the challenges confronting the school and the level of success achieved in the pursuit of school goals

In view of Thakral(2015) supervision is about evaluating and supporting teachers by bringing improvement in the teaching-learning process and their professional development. In addition, a supervisor is formally and officially designated person to assess and assist teachers in teaching-learning process and professional development. Additionally, effective supervision comprises tasks done by the head of schools and other school supervisors to direct and enlighten teachers about what should be done or have been done rather than faults findings. Cudjoe and Sarfo (2016) provide that, supervision intends to help teachers improve instruction by directly assisting them where as inspection aims to check the completion of the goals of curriculum by the teacher and in case of failure, to caution them critically.

The quality of education is adversely affected when the educational system is too loose and stakeholders are allowed to do whatever they like. In Laissez faire supervisory strategy does not help the quality of education in secondary schools as most people do not do what is right at the right time if there is no authority that stipulates what is to be done and also monitor them properly on the job. Achieving the purposes of improving supervision in secondary schools makes the achievement of the goals of secondary education much easier. This becomes more imperative and pressing as the cry all over the federation presently is about degeneracy in the education sector. Federal Republic of Nigeria (2004), Stated the goals of secondary school education as include the followings: UNESCO (2011) argues that the rapid expansion of students' enrolments, led to inadequate resources which 
make school management a much more complex. Meskil, (2005) observed that without strict adherence to good education it becomes a waste and even poses danger to all the sectors of the nation. It should be noted that good quality delivery begins from policy makers to resource providers, the teachers and the students. It has long been found that quality is never an accident; it has always been the result of high intentions, sincere efforts, and intelligent mission statement and focused as well as skillful implementation. In education, there is a broad agreement on a number of issues that define quality. They include higher academic standards, vigorous curricula, skilled and experienced teachers, updated textbooks, state of the arts laboratories and computing facilities, small class sizes, modern buildings and conducive environment for learning, strict discipline, solving parents amongst others. Quality education is needed to guarantee good future for the country. Supervision involves the stimulation of professional growth and the development of teachers, the selection and revision of educational objectives, materials of instruction and method of teaching and evaluation of instruction (Ogakwu, 2010).

The quality of instructional supervision in schools are most probably presumed to have effects on the teachers' expertise, practice and job satisfaction and on student learning outcomes. Moreover, Khalid, Komuji, and Veloo(2013) maintained that, if supervision is effectively implemented, it can promote teachers' performance in teaching which would be important to increase students' learning progress.

The supportive and educative process of supervision is aimed toward assisting supervisees in the application of theory and techniques to their works (Association for Counselor Education and Supervision, 2003). Numerous developmental models of supervision have been proffered in an attempt to further advance the sound application of supervisory services (Loganbill, Hardy; Delworth et al.2002; Watkins, 2004). Developmental models of supervision have in common a focus on supervisee change from novice to experienced professional through a delineated stage process with representative challenges facing supervisees at each level. The characteristics of each developmental stage afford supervisors the opportunity to enhance effectiveness through interventions aimed at facilitating further supervisee development Watkins, (2004)

School supervision exists nearly everywhere. Its origins date back to the birth of public education, when young nations used education to forge a common language and culture. Supervision was a key tool to ensure that all education staff respected the same rules and regulations and followed a similar programme De Grauwe, Anton. (2005.). A function is when a teacher sees his/herself as developmental in nature and not merely to impact knowledge parrot fashion (Butin, 2004). The tasks that teacher has to face include rendering direct assistance to individual students by helping the students to better understand the lessons. The teacher has to develop the class through group assignments and discussions the final product of all this efforts is an improvement in the students' achievement ( Butin, 2004).

Good supervisors seem to have many of the same qualities of good teachers and good counselors. They are empathic, genuine, open, and flexible. As they respect their supervisees as persons and as developing professionals, and are sensitive to individual differences (e.g., gender, race, and ethnicity) of supervisees. They are comfortable with the authority and evaluative functions inherent in the supervisor role, giving clear and frequent indications of their supervision of the counselor's performance. Even though, good supervisors really enjoy supervision, are committed to helping the counselor grow and evidence commitment to the supervision enterprise by their preparation for and involvement in supervision sessions. These supervisors' evidence high levels of conceptual functioning, have a clear sense of their own strengths and limitations as a supervisor, and can identify how their personal traits and interpersonal style may affect the conduct of supervision.

In Finland, it is undeniable that supervision was evidenced to support teachers' professional growth and development that resulted into quality teaching and learning (Alila, 2014; Alila, Määttä, \&Uusiautti, 2015). In a general view, supervision in schools 'rests on teamwork, reflection, and exchange of ideas among supervisors and subordinates (Pattison, 2010). Furthermore, supervision aims at a more reflective understanding of a teachers innumerable role and teacher identity (Paliokosta and Blandford, 2010). However, Tyagi(2010) claims that, supervision practices are still not taken in its generality.

According to Tyagi (2010) traditional inspectional model has long history since independence of India and evidences worthy up to date. Moreover, lack of mutual understanding between employee's and supervisors in an organization led to poor one-to-one care. In Ezekwensili's (2007) views, for the recent past decades there has not been comprehensive supervision of schools in Tanzania. Moreover, Ezekwensili argued that, because of poor supervision in Tanzanian schools, then failures have been evidenced in secondary schools. Education has been faced with insufficient supervision personnel, hence the teaching and learning 
process has been inactive in imparting knowledge and skills to learners.

Truly, supervision tasks involve the process of checking the effective execution of curriculum in schools. Ezekwensili's (2016) asserts that, the standards of education and performance of students can be improved if supervision is properly done. It is the task which is based on inspection and supervision action aimed achieving school pre-determined goals with exceptional emphasis on the utilization of available human and material resources.

The best example can be drawn from Ijaduola (2007) who conducted a study in Nigeria and the results of his study shows that, the success of any school lies in the extent at which supervision and leadership is been practiced and the degree at which students participates. Furthermore, the study insisted that, development of supervision plans or strategies is needed in schools. Not far from that, teachersuse different strategies of supervision to monitor the teaching and learning to their students in the schools. On the same note, Komakech, (2017) in his study on using zero money to tackle the challenge of universal education in Africa, particularly in Uganda, reports that, supervision provides both teacher and they are supervisors the chance to work as a team to improve students' learning.

In many countries of the world, there is a widespread claim that, academic standards are declining. The blame is shifted to the teacher who is considered not effective in the provision of teaching and learning environment in the classroom. However, the reality may be attributed by the fact that there is insufficient supervision from school heads and other relevant authorities. ISODEC (2011) in its study indicates that, one of the major causes of falling standards of education in northern Ghana is weak supervision of teachers in schools. In view of this standpoint, most of teachers know that they are not strictly supervised, they do not report to schools regularly to teach or render poor teaching to their students and that is what affects the standards of education.

When supervision is lacking in schools, students become rude to the teachers and it leads to lack of communication in the school, poor performance due to the poor teaching and learning. Other scholars (list such scholars here alphabetically) have given their own views by giving reasons of the weak supervision in India.

Like other parts of the world, Sub-Saharan Africa have long history in practicing supervision as the strategy for improving quality of education in schools. For instance, The Kenya Education Act (2013) provided the Minister of Education the responsibility to appoint Quality Assurance and Standards Officers (QASOs) for the reason of ensuring effective supervision in schools. This is to say that; the ministry was given mandatory function to ensure effective supervision are done at any school cooperatively. In other word, the ministry delegates the power to head of schools have a significant role to play in schools' supervision especially in ensuring that teachers' development is given a priority because quality teaching and learning in the requires competent and self- directed teachers who is capable in assessing and managing students' progress. It is probably from this background, ministry empowered head of school to ensure that teachers are effectively supervised in order to attain quality education in schools.

According to Okumbe (2007)head of schools have role to identify teaching and learning responsibilities for teachers and allocate the required resources that are available to accomplish the pre- set objective in school organization. Best of all head of schools have also the responsibility of arranging professional development training programme roster and indicate the number of teachers that could involve in each programme. Not far from that, head of schools should assist teachers through supervision to overcome challenges that hinder them from professional growth by providing effective guidance about professional abilities.

Fortunately, at the school level, the head of scholar ranges for the timetable in a manner that it could avoid collision and time wasting. For example, the head of schools must know in advance the required time for all the activities in the school. A school timetable can be arranged in the manner that different subjects could be able to be taught in different classes by different teachers at the same time without collision(Mbiti, 2007). The school head should ensure that teamwork among staff is encouraged so that all the various school activities may be included in the timetable and the whole process. Harmonizing activities in schools is necessary to in ensuring mutual understanding between head of schools and the teachers who are being supervised.

In order to ensure teachers are involved in various activities in the school, the head of school should ensure that opportunities where teachers can participate in programs such as revising school curriculum or designing school programs are well communicated to them. In other word, teachers should share they are knowledge and skills in reviewing curriculum and take responsibility for they are professional development (Dolgoff, 2005). Based on this standpoint, the responsibility of head of schools is to foster school conducive climate that encourages team supervision among teachers to enhance their professional competence.

In Tanzania, the task of school supervision is under the Ministry of Education Science, and Technology (MoEST) 
and Ministry of President's officer, Regional administration and Local government. Under this ministries, heads of schools executes they are responsibilities of supervision at facility level in monitoring teaching and learning activities as stipulated in circulars. The notable roles comprised of monitoring curriculum implementation, supervising the preparation and review of teaching and learning documents and ensuring proper students' assessment (MoEST, 2001).

The school heads employ a variety of supervision techniques that meet the diverse needs of teachers. This may increase greater chances of public satisfaction with the instructional process (URT, 2013). Instructional supervisors may acquire such techniques through their participation in in-service training programs. As Wiles and Bondi (2000) state, to be effective, instructional leaders must have both the knowledge and skills necessary to change the behaviors of teachers. These they can be acquired by attending seminars, conferences, and graduate classes.

Alkrdem, (2011) argues that, because school heads are expected to be in school throughout the year, they can discharge many supervisory functions more effectively than are external school supervisors, who may seldom visit schools. The possibility of schools pretending to satisfy external supervisors becomes irrelevant when school heads are entrusted with the supervision functions in their schools.

Supervision in Tanzania remains a problem as pointed out by Mbezi (2016). In his study, Mbezi identified some of the challenges hindering head of schools to execute effective supervision in their schools. The challenged that came up strongly comprised the issues like limited knowledge and experience by school heads, inadequate educational resources to facilitate supervision by school heads, inadequate training among head of schools and negative perception by teachers on supervision. Even though supervision is a requirement by law to all school heads, it is yet to be done effectively as required. Therefore, this study sought to find out the role of school heads supervision in improving quality of teaching and learning in public secondary schools in Ilemela District in order to comprehend its importance and contribution to school performance.

\section{Statement of the problem}

Supervision has great impact on quality of education in terms of teaching and learning. Through the government of Tanzania, there have been various initiatives to improve quality of education in terms of teaching, learning and performance. One of the initiatives was to ensure in the
Education Act of 1978 (Amended in 2016), school supervision is highlighted as the most important aspect of teaching and learning. Understanding this importance, school supervision has been decentralized down to school heads that are in good position to supervise all teachers under their jurisdiction. It is with no doubt these supervisions have been done and continue to be done but the question remains how continuous are they done? How effective are these supervisions? Supervision is yet to be done to its fullest and as required. Several challenges lead to ineffective school heads supervision including: ability for school heads to combine supervision with other activities, limited knowledge and experience by school heads, inadequate educational resources to facilitate supervision by head of schools, inadequate training and support which would be important in facilitating supervision effectively and negative perception by teachers on supervision (Mbezi, 2016).

The continuous ineffective head of schools' supervision contributes to poor quality of teaching and learning in most schools. If this problem is not addressed as desired in time, it will contribute to continuous poor performance among public secondary school students in the national exams, poor teaching environment in classroom, poor teacher and students' relations in the classroom, and negligence from the teachers since they know they will not be supervised as required. Therefore, this study aimed at exploring the role of school heads supervision in improving the competency of teaching and learning process among teachers in public secondary schools in Ilemela District in order to influence the government and policy makers to design, formulate and implement the existing relevant laws, policies and provide appropriate solution towards the problem.

\section{RESEARCH METHODOLOGY}

Creswell and Plano (2007) assert that, mixed research is the central premise that uses both quantitative and qualitative approaches to provide a better understanding of research problems in single study. The mixed research approach will be used just to triangulate the findings. Therefore, this study will employ convergent parallel research design as the framework to guide data collection, data analysis and data interpretation processes. Creswell (2012) in his study defined convergent parallel research design as a simultaneous framework of collecting both quantitative and qualitative together and analysed differently.This study will employ convergent parallel research design as the framework to guide data collection, data analysis and data interpretation processes. Creswell (2012) in his study defined convergent parallel research 
design as a simultaneous framework of collecting both quantitative and qualitative together and analyzed differently.

\section{Sampling Procedures}

The sample size of this study is 86 which is 16 percent of the total population. This study employed both probability and non-probability design in selecting samples in order to ensure reliability and validity of the data understudy

\section{Data Collection Methods}

The data collected quantitatively using questionnaires will be analysed through descriptive statistic using Statistical Package for Social Science (SPSS) version 20 computer program. Then the quantitatively analysed data will be presented and discussed in the chapter four using tables, charts and diagrams for easy communication to user. The data collected through interviews and focus group discussion will be analysed qualitatively using content analysis through thematically coded by themes and patterns and later been presented in chapter four for discussion through description to make sense of the findings ready for users.

\section{FINDINGS AND DISCUSSION}

This chapter is structured in three major sections: findings; and discussion in accordance with the research objectives posed in chapter one, namely to examine the strategies used by school heads in improving the quality of teaching and learning, to find out the challenges school heads face in executing supervision in improving the quality of teaching and learning, and establish possible initiatives to address challenges hindering effective school heads supervision that aim to improve the quality of teaching and learning.

\section{Demographic Data}

The demographic information considered in this study included gender, age and education level of the respondents. The researcher examined the participants' information in order to understand their appropriateness in answering the questions. The results are summarized in Table 4.5

Table 1: Students Demographic Information $(n=46)$

\begin{tabular}{lll}
\hline Category & Frequency & Percentage (\%) \\
\hline Age & 14 & 30.4 \\
16 & 18 & 39.1 \\
17 & 9 & 19.5 \\
18 & 5 & 10.8 \\
19 & & \\
Gender & 25 & 54.4 \\
Male & 21 & 45.6 \\
Female & & \\
Education Level & 46 & 100.0 \\
Form Four & &
\end{tabular}

Source: Field data (2020)

\section{Students Demographic Information by Age}

Table 1. indicates that, majority (39.1 per cent) of the students in Ilemela district were aged 17 years while those aged from 16 years accounts 30.4 percent; student aged 18 were equivalent to 19.5 percent and very few 10.8 percent of the students were aged 19. The findings show that many of the students studying in Form Four in Ilemela District had the right age to understand different issues related to learning.

\section{Participants Demographic Distribution by Gender}

Table 1.Describes the distribution of gender of the students who were involved in the study. The results establish that the majority (54.4 per cent) of the students enrolled in public secondary schools in Ilemela District were male while female students constituted 45.6 percent of the selected students. The findings denote that there a bit high disparity between male and female students schooling in the area, and the researcher intended to assess the gender 
of the participants with reason that, to include both gender so as to avoid acquiring biased information.

\section{Participant's distribution by education level}

Table 4.3 indicates that 100 percent of the students who were involved in the study were only form four. The researcher assumed that form four students could give reliable information pertaining to school heads supervision activities. The level of education is likely to shape the percentage of participants regarding the school heads supervision in improving quality teaching and learning in public secondary schools in Ilemela district.

The demographic information of the respondents showed that 54.4 percent were males while 45.6 percent were female implying that males participated more in the study

Table 2: Results Indicating Activities used to improve Academic Performance

\begin{tabular}{lll}
\hline Activity & Frequency & Percentage \\
\hline Evaluation of student's Academic Performance & 26 & 56.52 \\
Buying of sufficient teaching and learning materials & 12 & 26.09 \\
Solving students' problems in time and effectively & 8 & 17.39 \\
\hline Total & $\mathbf{4 6}$ & $\mathbf{1 0 0}$ \\
\hline
\end{tabular}

Source: Field Data (2020)

Strategies used by School Heads in Improving the Quality of Teaching and Learning

Under first objective of this study sought to examine the strategies used by school heads in improving the quality of teaching and learning in public secondary schools. In this case form four students were asked to indicate the extent to as compared to females. However, the significant difference is minimal to draw such a big conclusion. Students' age ranged between 16 and 19 (mean age average $=17.5$ ). Although majority of the students were aged between 16-19 years of age, a large proportion were 17 years old as shown in the Table.

The findings regarding the gender of principals in public secondary schools is in line with Murakami and Tornsen (2014) findings who highlighted that the total number of female secondary school students were lower compared to males. However, this was not a hindrance to the reliability of this study.

Table 3: Strategies used to Improve Quality of Teaching and Learning

\begin{tabular}{|c|c|c|c|c|c|}
\hline Statement & 5 & 4 & 3 & 2 & 1 \\
\hline $\begin{array}{l}\text { The head of school is friendly, approachable and accessible } \\
\text { to students without difficulties. }\end{array}$ & $6(13.04)$ & $12(26.09)$ & $8(17.39)$ & $11(23.91)$ & $9(15.57)$ \\
\hline $\begin{array}{l}\text { The head of school always creates and enhance conducive } \\
\text { learning environment in school. }\end{array}$ & $8(17.39)$ & $13(28.26)$ & $3(6.52)$ & $13(28.26)$ & $9(15.57)$ \\
\hline The head of school inspects teachers while they are in class. & $9(15.57)$ & $20(43.48)$ & $5(10.87)$ & $12(26.09)$ & - \\
\hline $\begin{array}{l}\text { The head of school cares about students, needs, problem in } \\
\text { order to meet your need and assist you in solving your } \\
\text { problems. }\end{array}$ & $13(28.26)$ & $20(43.48)$ & $6(13.04)$ & $5(10.87)$ & 2(4.34) \\
\hline The head of school motivates student's efforts. & $6(13.04)$ & $7(15.22)$ & $27(58.70)$ & $6(13.04)$ & - \\
\hline $\begin{array}{l}\text { The head of school involves students in decision making } \\
\text { process. }\end{array}$ & - & $9(15.57)$ & $27(58.70)$ & $8(17.39)$ & $2(4.34)$ \\
\hline
\end{tabular}

\section{Source: Field Data (2020)}

Table 3 indicates that, 39 percent agree that heads of schoolsare friendly, approachable and accessible to students without difficulties, 42 percent disagreed while 15.5 percent indicated undecided. From the study the which they agree or disagree with the statements provided in a Likert scale format. The responses of students are summarized and presented in Table 4.6. The scale is rated from the highest to lowest degree of agreement in the following order: 5=Strongly Agree, 4= Agree, 3= Strongly Disagree, $2=$ Disagree $1=$ undecided. 
important since it helps to be very close to the students so as to understand the challenges they face so as to improve quality teaching and learning. Most of students in many secondary schools are not very close to their head of school due to fear and therefore it is very important for heads of schools to be very friend with the students.

On the same note Mwesiga and Okendo (2018) indicated that, heads of schools have several roles to enforce teachers' teaching commitment like influencing, encouraging and helping followers to work towards attainment of the predetermined education goals. School heads are expected to improve students' academic achievement, teachers' commitment, bringing changes in education system, performance and accountability and seeking cross-education competitive labor force. They also need to be very close to students so as to understand their problems and being able to help them. Therefore, it is very important for the head of school to be friend and accessible to the students so as to understand their difficulties and help them so as to improve teaching and learning. It probably from this background, this study insists for more seminars to equip heads of schools with knowledge and skills to improve supervision which would influence quality teaching and learning in schools.

Through the focus group discussion with teachers at school A, one among them comments that:

The head of schools are not friend with us even the students as most of time they are very busy doing their stuff, as they believe that to be friend with students and they are subordinate will make students and teachers to not respect them that why they decide to stay away with teachers and students so as to create respect between teachers and the head of school but this is not good for supervision

Table 4.8 indicates that, 45 percent agreed that, heads of schools always make and develop favorable learning environment in school 34.7 percent disagreed while 15.5 percent indicated undecided. From the study, the majority disagreed that the heads of schools always generate and improve helpful learning environment in the schools. This means that there is a problem due to the fact that on the issue of supervision the head of school should create learning environment in school by ensuring that, there is learning interaction between a students and teachers and also ensuring both students and teachers feel comfortable and in the friendly environment which help to enhance quality teaching and learning.

This is supported by Tobias (2019) who conducted a study on the contribution of instructional supervision in the teaching and learning process in Public secondary schools in Geita Region, Tanzania. The study finding showed that, school supervisors have a central role to play in ensuring that the teaching and learning process is enhanced. The author suggests that school heads have to induce organizational culture and stewardship in meeting the goals of teaching and learning in schools. Organization culture is very important to be considered by the heads of schools, since it help on the issue of monitoring and evaluation during supervision process. Therefore, it is very important for the heads of schools to create effective learning environment which helps to improve quality teaching and learning

Through the focus group with teachers in school $\mathrm{C}$, one said that:

It is very important for the head of school to create effective environment for the teachers and students so as to make them work so hard which at the end will help to improve quality education and at the end they will be able to achieve good academic performance among the student this will be done by creating friendship relation which will help to enhance effective teaching and learning process for both teachers and students

Table 4.8 indicates that, 71 percent agreed that the heads of schools care about students 'needs and problems in order to assist them in solving their problems 23.8 percent disagreed while 4.3 percent undecided, From the study it was found that some respondents disagree that heads of schools care about students' needs and problems in order to assist them in solving their problems. Education institution expects the head of school to be a problem solver and listener to both teachers and students so as to improve quality teaching and learning. This concurs with Mwesiga and Okendo (2018) who ascertain that, heads of schools have several roles like influencing, encouraging and helping followers to work towards attainment of the predetermined education goals. Therefore, by doing all that the heads of schools will be able to improve quality teaching and learning for both students and teachers.

Table 4.8 indicates that, 28.2 percent agreed that, the head of school motivates student's efforts, 71.7 percent disagreed. From the study it was found that majority strongly disagree that the heads of schools motivate students' efforts. Students' motivation is very important for the improvement of quality teaching and learning. If students are motivated, they will be able to pay attention in the classroom and at the end teaching and learning will be effective. Therefore, it is very important for the heads of schools to motivate students by giving them some gifts so 
as to give them courage to study hard and at the end; academic performance of the students will be improving.

Through focus group discussion with teachers in school B, one comments that:

The head of school should motivate students and teachers by giving to them reward and recognition to those who are doing well and for the students who perform well in their study, by doing this will make both students and teachers to work very hard which at the end will help to improve effective teaching and learning so as to improve quality education which will help to ensure good performance among the students

This is supported by Michael (2017) who ascertains that, heads of schools should make regular checking of teachers' lesson plans, observing how teaching and learning takes place, persisting students' monitoring on academic progress and timely feedback to both teachers and students. To ensure that supervision process is effectively done by heads of schools, both teachers and students should collaborate with the heads of schools so as to make schooling more effective. Motivation for both students and teachers is very important and it should be given priority by all heads of schools.

Table 4.8 indicates that, 15.5 percent agree that, the head of school involves students in decision making process, 76 percent disagree while 4.3 percent undecided. From the study it was found that majority strongly disagree that if head of school involves students in making decision about their learning interests. This means that the heads of schools are not doing their work of involving students in decision making; the thing which is not good for improving teaching and learning. Students' involvement in decision making is very important since it helps students to be a part of all things which are decided in a school. Additionally, it helps the heads of schools to know what students suggest on improving quality schooling and at the end even the academic performance of the students will be improved.

Under the first objective, which sought to find out strategies used by school heads in improving the quality of teaching and learning, the findings indicated that schools are applying several strategies. Among the strategies that came up strongly are: promotion of professional development, ensure availability of teaching and learning materials, effective supervision of teaching and learning documents. The findings of each of these strategies are as discussed below.

\section{Promotion of Professional Development}

According to participants' viewpoints, professional development was viewed as one of the strategies used by most heads of schools to improve teaching and learning.In Brooker and Jennifer (2015) view, professional developments are the effort and strategies by the government or non-governmental organizations to improve the skills, abilities, and knowledge among teaching and non-teaching workforce. It is from this background, head of school A argued that, "It is important to update the knowledge and skills for both heads of schools and working staff for the reason that it would equip both of them with the ability to promote quality teaching and learning in schools". In line with this understandings, Okumbe (2007), contented that, the role of head of schools is to draw up a training programme roster and indicate the number of teachers that could participate in each programme when it is organized. Moreover, school heads should assist teachers through supervision to diagnose and remedy challenges that hinder teachers' growth and provide effective guidance in promoting teachers' professional abilities which meet the challenge of changing education system.

\section{Availability of Teaching and Learning Materials}

According to participants' viewpoints, the adequate teaching and learning materials is another strategy that came up strongly during this study. According to Seema(2013) views, adequate provision of teaching and learning materials ensure the right to access quality teaching and learning in schools. Moreover, head of school B noted that, "Availability of both textbooks and supplementary books in school motivate students to learn independently of which it becomes easy for teachers and heads of schools to supervise teaching and learning process in schools". Likewise, WEOA added that, "Teaching and learning materials such as books, laboratory chemicals and teaching aids simplify the process of teaching and learning. Consequently, supervision becomes easy and successful among heads of schools". Based on this standpoint, this study concludes that teaching and learning materials foster quality teaching and learning in schools.

\section{Supervision of Teaching and Learning Documents}

In line with participants' viewpoints, supervision of teaching and learning documents is viewed as the strategy for promoting quality teaching and learning in schools. According toamong and Ogbadu (2010), adequate supervision of teaching and learning documents produces high quality teaching and learning process in schools. In other words, supervision of teaching and learning documents is very crucial that enhances opportunity to 
improve competence of teachers and promotes effective management of teaching and learning process. It is from this notion, one of the participants in group discussion, said, "Effective supervision of teaching and learning documents such as lesson plans, lesson notes, schemes of work and action plans foster competence among teachers in schools". It is from this background, this study found out that heads of schools should acquire supervision knowledge and skills that would be important for improving teaching and learning process in schools.

\section{Challenges Facing Head of Schools}

Under the second objective, this study aimed at identifying the challenges that heads of schools face during supervision in improving the quality of learning and teaching in public secondary schools. To achieve the objective, students were asked to mention only five challenges that their heads of schools face during the implementation of supervision of learning activities in their schools. Table 4. summarizes the results.

Table 4. Results Showing Challenges Facing Heads of Schools

\begin{tabular}{lll}
\hline Challenge & Frequency & Percentage \\
\hline Heavy workload for Head of Schools & 7 & 15.22 \\
Inadequate teaching/learning materials & 18 & 39.13 \\
Lack of enough knowledge on supervision & 15 & 32.61 \\
Lack of confidence & 6 & 13.04 \\
\hline Total & 46 & 100 \\
\hline
\end{tabular}

Source: Field Data (2020)

Table 4. shows the challenges that affect heads of schools in achieving effective supervision of teaching and learning in schools. The findings show that excessive work load had a magnitude of $7(15.2$ percent $)$, in adequate teaching and learning materials 18 (39.1 percent), poor supervision knowledge 15(32.6 percent), and lack of heads of schools' confidence $6(13$ percent $)$ that makes a total of $46(100$ percent) respondents involved in this study. The identified themes under such challenges are discussed below.

\section{Excessive Workload}

According to participants' viewpoints, heavy workload for heads of school is among the challenges found out in this study to hinder the heads of schools in achieving quality teaching and learning. This means that, in most of schools, the heads of schools have many tasks to perform per day which at the end they fail to perform at satisfactory level. This challenge affect a lot in most of educational institutions which, as the result, make poor quality teaching and learning and even affect academic performance of the students. From the study it was found that the head of schools have so many task to perform as the result make them to fail to perform effective so as to be able to improve teaching and learning process.

Through the interview with the head of school $\mathrm{C}$, he said that,

For sure we have many tasks to perform, attending meetings, preparing reports, and conducting seminars with teachers. Therefore, it is difficult for us to perform all these tasks on time and as the result we fail to maintain supervision like monitoring teaching and learning. Some time we found ourselves with a lot of work and we are the one who should be responsible for that at the end we fail to manage them and hence affect supervision on teaching and learning

Additionally, head of school B, also commented that,

Supervision is very vital for the development of quality teaching and learning but sometimes we fail to make it effective due to the fact that we have so many responsibilities to perform. The workload is a big challenge in improving quality teaching and learning and some time we face the challenge of controlling students behavior which also is very problem due to so many task to it affect even supervision in teaching and learning

In Masao' (2017)made the assessment of heads of secondary schools' supervision in teaching and learning process in Kinondoni, Dar es Salaam. The results showed that, poor teaching and learning is due to the ineffective 
supervision which results into failure to achieve the organizational set goals. He added that, sometimes heads of school have lots of activities and at the end they fail to maintain supervision. Therefore due to the a lot of work among the head of schools it affect even supervision and at the end affect even teaching and learning

\section{In adequate Teaching and Learning materials}

According to participants' viewpoints, inadequate teaching learning materials were viewed as the challenges that face the heads of schools in improving quality teaching and learning. In most of schools especially government schools there is lack teaching and learning resources to improve quality of teaching and learning process. Supervision is there but supervision without teaching and learning materials is nothing, because both teachers and students need enough materials for teaching and learning. Therefore, to improve teaching and learning and maintain effective supervision there should be enough teaching and learning materials.

Through the interview with WEO, he commented that,

In most of our schools the teaching and learning materials are not enough. This hinders the whole process of supervision among the heads of schools. You may find that in many schools both students and teachers share a book, something which is not good for improving teaching and learning process. This lack of enough teaching and learning material make teachers and students to fail to perform effective as students fail to have wide understanding about the subject due to the shortage of teaching and learning material which at the end affect teaching and learning process

This is supported by Asiyai(2016)who indicated that, both students and teachers experienced lack of teaching and learning resources which affect teaching and learning process. In many schools there are few books which make supervision to become a challenge. Therefore, teaching and learning materials are very important to supervision among the heads of schools so as to improve teaching and learning. Lack of enough teaching and learning material have beeb a problem to many schools and this is due to the lack of enough budget set by government through the ministry of education, the fund in educational instructional especially the government schools are not enough at the end they fail even to buy the teaching and learning resources which will help them to improve teaching and learning process as the result it affect academic performance of the students

\section{Poor Supervision Knowledge and Skills}

Likewise, during this study finding indicate that lack of enough knowledge on supervision among the heads of schools is among the challenges that face the heads of schools. There is lack of knowledge concerning school supervision among the heads of schools due to the fact that most of do not attend seminars and workshops to have knowledge on supervision. Lack of knowledge has affect heads of schools since most of them are not aware of their roles as school supervisors. This affects quality teaching and learning and academic performance of the students.

In the interview, the DEO, said,

Most heads of schools lack
knowledge on supervision; so most
of them do not know their roles on
school supervision. This becomes a
challenge on improving quality
teaching and learning process since
the schools lack effective
supervision due to the lack of
knowledge among heads of schools.
The head of schools lack the
knowledge on how to use effective
their leadership skills and to
promote effective relationship
between them and teachers together
with the students at the end they fail
to maintain
communication at the school and
end up being in conflict with both
teachers and the students

Zabonimpa (2011)conducted a study in Entebbe Uganda on the influence of head teachers general and instructional supervisory practices on teachers' work performance in secondary schools. The study findings emphasized that, head teachers have limited general instructional supervision in secondary schools. They lack awareness of their job description, and lack support from experienced teachers due to the fact that they are more senior and have superficial expertise compared to their head of schools. Therefore, awareness on supervision is very important on improving teaching and learning process.

\section{Lack of Confidence among Heads of Schools}

In this study, findings indicate that lack of confidence is one of the challenges that face the heads of schools in supervision. This means that most heads of schools do not have confidence on supervision and this is caused by lack of knowledge on supervision. As the result they delegate 
their responsibility to other teachers. Some of them think that they can create conflicts with teachers if they supervise them as required. Kurebwa, Wadesango and Wadesango (2015) argued that, most of the deputy head teachers lack confidence in supervising role, and their counter head teachers do not recognize the presence of their assistants. Therefore, most of the heads of schools do not have enough knowledge on supervision due to the fact that most of them are given that position because of their experience and not because of their knowledge. This has been affecting most of schools in Tanzania on the issue of teaching and learning process. Then, lack of confidence among the heads of schools is the big challenge and it is associated with lack of knowledge among the heads of schools on supervision which at the end affect quality teaching and learning process. Speaking of this situation, one of the participant in focus group discussion pointed out that, "Some of heads of schools lack confidence when it comes to perform their supervision responsibilities, consequently, they misuse their power vested by intimidating their subordinates". It is from this notion, this study emphasizes on supervision training among heads of school to stimulate them with knowledge and skills to boost their confidence.

Initiatives to Address Challenges Hindering Effective School Heads Supervision

The last objective of this study aimed at establishing possible initiatives to address the challenges hindering effective school heads supervision that aim to improve the quality of schooling process. For this case, respondents were requested to mention five ways which can be used to improve school heads supervision. The following were the answer from respondents as presented in Table 5

Table 5: Initiatives to Address Challenges Hindering Effective School Heads Supervision

\begin{tabular}{lll}
\hline Challenge & Frequency & Percentage \\
\hline Provision of skills and knowledge on supervision & 15 & 32.6 \\
Government should increase funds & 10 & 21.7 \\
Heads of school should make regular checking of teachers' lesson plans & 12 & 26.0 \\
There should be effectiveness on school leadership & 9 & 19.0 \\
\hline Total & 46 & 100
\end{tabular}

Source: Field Data (2020)

Table 5 indicates the initiatives found out help heads of schools in achieving effective supervision of teaching and learning in schools. The findings show that provision of skills and knowledge on supervision had a magnitude of 15(32.6 percent), government to increase funds $10(21.7$ percent, regular training so as to enable the heads of schools to have skills and knowledge on supervision 12(26 percent) and effectiveness in school leadership 9(19 percent) that makes an aggregate of $46(100$ percent) respondents involved in this study. The identified theme under initiatives employed by head of schools to improve quality teaching and learning have been discussed below.

\section{Provision of Skills and knowledge on Supervision}

According to participants' viewpoints, findings indicate that provision of skills and knowledge on supervision to heads of schools and teachers would be important for improving quality teaching and learning. For emphasis, one of the participants in the focus group discussion said;

Training is very important for the heads of schools so as to give them skills and knowledge on supervision since most of them do not know their responsibilities on supervision and when they are asked they respond that they do not know. The skills and knowledge will help them to be effective on supervising both students and teachers, and hence help them to improve quality of schooling. The skills and knowledge should be provided by establishing educational seminar and work shop to be able to provide skills and knowledge among the head of schools which at the end will help to improve teaching and learning process

As noted by Balta, Arslan and Duru (2015) in their studies about the investigation on the effect of on-the-job train on teacher achievement. The findings reveal that, teachers are the engine of educational development and they have a vast impact on students' positive academic achievement. Therefore, they have the responsibility of updating their knowledge and skills. In Tanzania nowadays, teachers are given a chance to increase their knowledge so as to make teaching and learning more effective. However, the 
problem is that there is no effective supervision in educational organization due to the fact that the heads of schools are not aware of their role in supervision. Therefore, there should be regular training so as to enable the head of schools to have skills and knowledge concerning supervision for improving quality teaching and learning.

\section{Government should increase funds}

In view of participants' standpoints, findings showed that the government should increase funds to facilitate inservice training programme to heads of schools so as to improve quality teaching and learning. There is lack of funds in most of schools due to the meager budget on the Ministry of Education which affect a lot the process of inservice training among head of schools Heads of schools should facilitate in-service training programme to teachers which will help them to have enough skills and knowledge on supervision and hence help to improve quality schooling.

In the interview, the head of school A, said,

The government should ensure that there is enough fund to support teacher training through in-service training by preparing seminars and workshops for the heads of schools to be able to improve their skills and knowledge on supervision. This will enable schools to improve teaching competency among teachers. Also the government should ensure that there is enough teaching and learning material which will be used by both teachers and students so as to be able to improve teaching and learning process

This is in line with Malunda, Onen, Musaazi and Oonyu (2016) who conducted a study in Uganda on instructional supervision and the pedagogical practices of secondary school teachers. They comment that, the government should increase funds to facilitate in-service training programme to teachers. Heads of schools as supervisors need to get training so that they can get new techniques for supervising the schools to enhance performance. The provision of enough funds to support teachers training is very imperative for improving quality teaching and learning. Therefore from the student it was found that the government should ensure that there's enough fund in education sector which will be used to improve teaching and learning process in public secondary schools and teaching and learning material should be distributed equally in all secondary schools.

\section{Regular checking of teachers' lesson plans}

In view of participants' standpoints, heads of school should make regular checking of teachers' lesson plans. This is very important due to the fact that most of the heads of schools forget their responsibility of checking teachers' lesson plans and believe it is not their responsibility. Regular checking of lesson plans can help the heads of schools to know if teachers observe their responsibility. Michael (2017) ascertains that, heads of schools should make regular checking of teachers' lesson plans, observing how teaching and learning takes place, persisting student monitoring on academic progress and timely feedback should to both teachers and students. To make sure that supervision process is effectively done by heads of schools, both teachers and students should collaborate with the heads of schools so as to make teaching and learning more effective.

\section{Effectiveness on school leadership}

In this study, findings indicate that, there should be effectiveness on school leadership so as to improve quality teaching and learning. Good leadership helps to understand different challenges faced by both teachers and students and be able to help them. A good leader is always very friendly with both students and teachers. By doing so, teachers and students will be very close to him/her so as to discuss different issues which can facilitate to improve quality schooling process. Commenting on this situation, one participant said, "There should be good leadership in schools, a leader who is responsible, lovely, a listener, and who can make strong decisions concerning teaching and learning. That will improve quality teaching and learning". In the same line, Mwesiga and Okendo (2018) examined the effectiveness of heads of schools in supervising teachers' activities in secondary schools in Kagera region. The results showed that, there is a need to continue investing the effectiveness of school leadership in supervising teachers' activities in secondary schools. It seems that the heads of schools provide information that they are doing great in the supervision process, but the opposite is true. Hence, the government, through the Ministry of Education, should make a close follow up on the reports from heads of schools to improve teaching and learning effectively.

\section{CONCLUSION}

Head of schools play a great role in making sure that quality learning is realized in schools. Their supervisory role is of most importance as it improves teachers' competency and students' academic excellence. The study established that heads of schools orients new teaching staff, supervise curriculum, timetabling and monitor 
students' academic progress to improve quality of schooling process in schools. These roles were valued very highly as being performed always. Provision of adequate teaching/learning materials was also rated high. Head of schools were found to rarely provide such materials despite their importance in facilitating quality teaching and learning in schools. Visits to classrooms to observe teachers' lessons by head of school were rated low by teachers themselves.

The major challenges faced by heads of schools included inadequate teaching/learning materials, lack of finances, in-adequate staffing, and high turnover of teachers. Suggestions were advanced by respondents on how heads of schools can improve their supervisory roles in their schools. Heads of schools are to involve teachers in planning and executing of their supervisory roles in order to improve quality of teaching and learning. There should also be a system of monitoring of students' academic performance, and conducting face to face meetings.

\section{RECOMMENDATIONS}

Based on the findings of this study, the study provides both recommendation for action and recommendation for further study.

Head of schools should be setting time for instructional supervision in schools because it is one of the roles that influence students academic achievement positively.Heads of schools should be pro-active in organizing face-to-face meetings with teachers and students in the schools. They should also facilitate teachers' attendance of trainings outside the school as guided by the needs of individual teachers and schools.

On the other hand, education officers should lay emphasis on development and application of technical skills by heads of schools in order to ensure effective motivation to teachers and students to respond positively to various instructional activities in their schools.

In addition, seminars and workshops should be emphasized to reinforce heads of schools' visits to classrooms, to observe lessons and provide feedback to teachers. Consequently, there is need to inculcate in teachers the new approaches of supervision such as clinical supervision and collegial supervision. The in-service training of teachers needs to be emphasized in schools such that teachers take initiative to develop themselves and then be supported by their heads of schools.

The school heads should use differentiated supervision approach in supervising the teachers in their respective schools to ensure that they could met the individual needs of each teachers on their uniqueness.
There is also need to ensure that the delegated duties of heads of schools to directors of studies and heads of departments are supervised as some may abdicate.

The study also recommends that the Ministry of Education should reinforce supervision-based training, seminars, workshops, and refresher courses countrywide for secondary school head teachers and deputy head teachers. By so doing, even those who missed out supervision courses at universities or teachers 'colleges would benefit.

\section{REFERENCES}

[1] Adewale, S. O., Adeleke, E. A., Toyin, F. A., \& Rotimi, O. (2014). School Inspection or, and Supervision Effects in Public Secondary Schools in Ogun State, Nigeria: Where are we and where do we go? International Journal of Humanities and Social Science Invention, 3(6),74-80

[2] Alila, S., Määttä, K., \& Uusiautti, S. (2016). How Does Supervision Support Inclusive Teacherhood? International Electronic Journal of Elementary Education, 8(3), 351-362.

[3] Alkrdem, M. (2011). School-based instructional supervision in Saudi Arabian public secondary schools. (PhD thesis), University of York.

[4] Anton, D. G. (2005). Improving Quality through SchoolBased Management: Learning from International Experiences. International Review of Education, 51(4), 269-287.

[5] Archibong, I. F. (2012). Instructional Supervision in the Administration of secondary Education: a panacea for quality Assurance. European scientific journal, 8(13), 6170.

[6] Arong, F. E., \& M. A, (2012).The major case of declining quality of education in Nigeria administrative perspectives. A case of Dekina local government area. Canadian Social Science, 6(3), 61-76

[7] Asiyai, R. I. (2016). Relational study of in-service training, teaching effectiveness and academic performance of students. Journal of Teaching and Education, 5(2), 205216.

[8] Balta, N., Arslan. M., \& Duru, H. (2015). The effect of inservice training courses on teacher's achievement: A metaanalysis study. Journal of Education and Training Studies, $3(5), 19-28$

[9] Bondi, J. (2000). Supervision: A guide to practice. Englewood Cliffs, NJ: Prentice Hall.

[10] Brooker, W. Jennifer, C. (2015). Professional Development and Teacher Change: The Missing Leadership Link. Journal of Science Teacher Education. U.S.A: The Association for Science Teacher Education.

[11] Cresswell, J., Clark, P. V. (2007). Designing and conducting Mixed methods research Thousand Oaks, CA: Sage

[12] Creswell, J. W. (2012). Research Design: Qualitative and quantitative approaches. London: Sage Publications Inc.

[13] De Grauwe, P., \& Claudia, S. C. (2001). Monetary Policy in a Cashless Society Available at Retrived from SSRN: $\underline{\text { https://ssrn.com/abstract=261872 }}$

[14] Ezekwensil, O. (2007). Our educational system. Paper presented at the Presidential Forum of Education, Abuja. 
[15] Ezekwensil, O. (2016). Academic supervision as a correlate of students' academic performance in secondary schools in Ekiti State, Nigeria. International Journal of Educational Policy Research and Review, 4(1), 8-13.

[16] Fisher, D. (2011). Setting the "Opportunity to Read" Standard: Resuscitating the SSR Program in an Urban High School. Journal of Adolescent \& Adult Literacy, 48(2), 80-92.

[17] Glickman, D. C., \& Gordon, P. S. (2004). The Basic Guide to Supervision and Instructional Leadership ( $3^{\text {rd }}$ Edition) Allyn \& Bacon Educational Leadership.

[18] Glickman, D. C., \& Gordon, P. S. (2004). The Basic Guide to Supervision and Instructional Leadership (3 ${ }^{\text {rd }}$ Edition) NewYork: Allyn \& Bacon Educational Leadership.

[19] Ijaduola, K. (2007). Decision Making strategies for effective crisis Management among Nigeria School principals. $\mathrm{PhD}$ thesis. Nigeria.

[20] ISODEC. (2011). Weak supervision destroying the quality of Ghana's public education. Journal of Educational Sciences, 1(2), 1-7.

[21] Komakech, A. R. (2005). School Practice Supervision and Performance of Student Teachers in Higher Institutions of Learning in Uganda: Empirical Evidence from Kyambogo University and Ndejje University. Journal of Education \& Entrepreneurship, 5(2), 16-35.

[22] Kurebwa, M., Wadwsango, N., \& Wadesango, V. (2015). Challenges faced by deputy heads in supervising teachers in primary school. International Journal of Educational Sciences, 9(2), 187-197.

[23] Malunda, P., Onen, D., Musaazi, S. C. J., \& Oonyu, J. (2016). Instructional Supervision and the Pedagogical Practices of Secondary School Teachers in Uganda. Journal of Education and Practice, 7(30), 177-187.

[24] Masao, M. (2017). Studies in the Intellectual History of Tokugawa Japan. Translated from the Japanese to English by M. Hane. University of Tokyo Press.

[25] Mbiti, M. D. (2007). Foundations of School Administration. Nairobi: Oxford University Press.

[26] Meskil, B. (2005) 'Supervision: A co-operative exercise in accountability' in M. Marken and M. Payne (eds.) Enabling and Ensuring. Supervision in practice, Leicester: National Youth Bureau.

[27] Michael, G. (2017). The impact of educational supervision on students' academic performance in Ukerewe District, Tanzania. Retrieved from academia.edu.on 22 February 2020

[28] Mohanty, J. (2008). Educational administration supervision and school management. New Delhi: Deep \& Deep Publications

[29] Murakami, E., Pollock, K., \& Törnsen, M. (2014). School principals' standards and expectations in three educational contexts. Canadian and International Education Journal, 43(1), 78-90.

[30] Mwesiga, A., \& Okendo, E. O. (2018). Effectiveness of heads of schools in supervising teachers' teaching activities in secondary schools in Kagera region Tanzania. International Journal of Scientific Research and Management, 6(4), 91-117.

[31] Ogakwu,V. N. (2010). A Comparative analysis of supervisory control measures in Public and Private secondary schools in Enugu state. Knowledge Review, 21(3), 25-32

[32] Okendu, J. N. (2012). The influence of instructional process and supervision on academic performance of secondary schools of River state in Nigeria. Academic Research International Journal, 3(1), 147-151.

[33] Okumbe, J. A. (2007). Educational Management: Theory and Practice. Nairobi: Nairobi

[34] Paschal, M. J. \& Mkulu, D. G. (2020). Teacher- Students' Relationship and Students 'Academic Performance in Public Secondary Schools in Magu District, Tanzania. Journal of Research in Education and Society, 11(1), 20-3. http://www.icidr.org/jresv11nol-content.php.

[35] Paschal, M. J., Nyoni. T. T. \& Mkulu, D. G. (2020). The Role of Cooperative Learning in Attaining Inclusive Learning in the Classroom, Creativity and Innovation in Secondary Schools in Mwanza Region - Tanzania. International Journal of English Literature and Social Sciences, (IJELS), 5(2). $\quad$ http:/ljournalrepository.com/index.php/ijels/article/view/1730

[36] Sarfo, F. K \& Cudjoe, B. (2016). Supervisors' Knowledge and Use of Clinical Supervision to Promote Teacher Performancein basic schools. International Journal of Education and Research, 4(1), 87-100

[37] Seema, O. S. (2013). Implementing right to education: Issues and challenges. New York: Research

[38] Tyagi, R. (2010). School-based instructional supervision and the effective professional development of teachers. $A$ Journal of Comparative Education,40(7), 111-125.

[39] Veloo, A., Komuji, A.M., \& Khalid, R. (2013). The effects of clinical supervision on the teaching performance of secondary school teachers. Procedia - Social and Behavioral Sciences, 93(2013), 35-39.

[40] Watkins, E. (2004). Adaptive and maladaptive ruminative self-focus during emotional processing. Behaviour Research and Therapy, 42(8), 1037-1052.

[41] Zabonimpa, B, J. (2009) Influence of head teachers General and instructional supervisory practices on teachers work performance. (Unpublished Master's thesis, Kamba University). 